\title{
Biomonitoring of Mercury in Hair among a Group of Eritreans (Africa)
}

\author{
Maria Luisa Astolfi ${ }^{1, *}$, Carmela Protano ${ }^{2}$, Elisabetta Marconi ${ }^{2}$, Lorenzo Massimi ${ }^{1}{ }^{(0)}$, \\ Daniel Piamonti ${ }^{3}$, Marco Brunori ${ }^{3}$, Matteo Vitali ${ }^{2}$ (D) and Silvia Canepari ${ }^{1}$ (D) \\ 1 Department of Chemistry, Sapienza University, Piazzale Aldo Moro 5, I-00185 Rome, Italy; \\ 1.massimi@uniroma1.it (L.M.); silvia.canepari@uniroma1.it (S.C.) \\ 2 Department of Public Health and Infectious Diseases, Sapienza University, Piazzale Aldo Moro 5, \\ I-00185 Rome, Italy; carmela.protano@uniroma1.it (C.P.); elisabetta.marconi@uniroma1.it (E.M.); \\ matteo.vitali@uniroma1.it (M.V.) \\ 3 Department of Cardiovascular, Respiratory, Nephrology, Anaesthesiology and Geriatric Science, \\ Sapienza University, Viale del Policlinico 155, I-00161 Rome, Italy; daniel.piamonti@gmail.com (D.P.); \\ marco.brunori@uniroma1.it (M.B.) \\ * Correspondence: marialuisa.astolfi@uniroma1.it; Tel.: +39-0649913384
}

Received: 31 January 2020; Accepted: 14 March 2020; Published: 15 March 2020

check for updates

\begin{abstract}
Small-scale or artisanal mining, using gold-mercury amalgamation to extract gold from ore, is a significant source of exposure for the workers and nearby populations. Few studies on hair mercury $(\mathrm{Hg})$ have been conducted in Africa despite the fact that Africa has several gold deposits. No studies have been conducted in Eritrea that is one of the emerging gold producing countries in Africa. The aim of the study was to assess the $\mathrm{Hg}$ concentration in hair samples $(n=120)$ of a population living in Asmara, capital of Eritrea, and to evaluate the influence of some factors on the Hg levels in hair. Information on age, height, weight, occupation, smoking and fish consumption of participants were collected via questionnaire. Hair $\mathrm{Hg}$ concentration was significantly higher among women compared to men $(p<0.001)$ and among women preparing spicy products in Medeber market compared to those who did other jobs $(p=0.010)$. These results highlight the need for routine biomonitoring surveys and for health promotion campaigns devoted to local decision makers and workers.
\end{abstract}

Keywords: biological monitoring; hair analysis; toxic element; human health

\section{Introduction}

Mercury $(\mathrm{Hg})$ is a naturally occurring element that can be distributed in the environment by both natural processes and human activities [1]. Hg is recognized as a dangerous environmental pollutant due to its high persistence in the environment and its toxicity to several biological species, including humans [2-4]. The entire global population is potentially exposed to $\mathrm{Hg}$ due to its long-range transport and its ubiquity in global marine ecosystems [5]. Hg can be found in three main forms: elemental, inorganic and organic (such as methylmercury, $\mathrm{MeHg}$ ), each with their own implications for human health [6,7]. People may be exposed to elemental or inorganic $\mathrm{Hg}$ through inhalation of ambient air, during occupational activities and from dental amalgams [8], but the main nonoccupational exposure of humans to $\mathrm{Hg}$ is in its organic form ( $\mathrm{MeHg}$ ), considered the most toxic species of $\mathrm{Hg}$ [9]. The main route of exposure to $\mathrm{MeHg}$ is through diet, by the consumption of fish and seafood [10,11]. Small-scale or artisanal mining, using gold-mercury amalgamation to extract gold from ore, is a significant source of exposure for the workers and nearby populations [12,13]. Besides, metallic $\mathrm{Hg}$ wastes are usually dumped into or near watercourses. These discharges can lead to high MeHg levels in fish of these water bodies [14]. In this way, Díez et al., [15] found that mean Hg levels were greater in people living 
close to industrial mining activity sites compared with a site placed hundreds of kilometers away. To our knowledge, in Africa, the impact of $\mathrm{Hg}$ contamination has not been thoroughly studied and the human exposure assessment has been very limited, despite the fact that artisanal and small-scale gold mining continues to expand and to increase in some hotspots in African countries, in response to the global demand for gold [12,16-18].

Exposure to toxic $\mathrm{Hg}$ levels can cause neurological, renal, cardiac and reproductive disorders as well as genetic damage [19-21]. Human exposure to $\mathrm{Hg}$ can be assessed using an environmental monitoring approach. In this case, the $\mathrm{Hg}$ level in specific matrices such as food, water and air can be determined and external exposure to $\mathrm{Hg}$ estimated [11]. However, this method requires a lot of data on $\mathrm{Hg}$ levels in different matrices and does not allow one to have information on the real dose absorbed by the human body (body burden) [22]. For this reason, the biological monitoring approach is currently recognized as a more appropriate tool for assessing the exposure and the related risks for human and environmental health [23-28]. Hg concentrations in blood and hair have been used as biomarkers to assess the human exposition to this element [29]. The total $\mathrm{Hg}$ in human hair is a good indicator of long-term $\mathrm{Hg}$ exposure, particularly for methylmercury [30]. The hair-to-whole blood ratio has been estimated to be about 250 to $1[30,31]$. In this way, hair samples appear as an interesting alternative because it is a noninvasive matrix and it is easy to sample [32-34].

In the present study, we assessed the exposure to $\mathrm{Hg}$ in the hair of a group of residents in Asmara, capital of Eritrea (Africa), due to the possible contamination by small-scale or artisanal extraction of gold from deposits present in a few kilometers away from Asmara, and due to the processing of metal objects (for men) and spices (for women) at the Medeber market. We also compared the results with similar international studies and performed an analysis of the main exposure predictors. The risk was characterized by comparing the Hg levels in hair using international health-based guidance values.

\section{Materials and Methods}

\subsection{Study Design and Sample Collection}

This study included 120 adult hair samples selected in Asmara, the capital of the small East African country of Eritrea. The subjects were randomly selected from a larger population of 840 subjects participating in 2017 in the "Medeber project". This project, carried out in collaboration with the Italian nonprofit organization "ASS.ITER. Onlus", includes intervention and epidemiological studies focused on Eritrean adults. In particular, about $53 \%$ of the volunteers $(N=64$ individuals; 32 males and 32 females) were employed at the Medeber market in Asmara (Table 1). In this market, men hammer, cut, weld and transform metal objects and old machinery into something useful, while women prepare "berbere", a mixture of spices (like peppers, ginger, cardamom, coriander and cloves), and other spicy products [35].

The study was approved by the Minister of Health of Eritrea through acknowledgement of the ASS.ITER. Onlus, within the "Medeber project" and it was carried out according to the Declaration of Helsinki. All the recruited individuals received clear information on the objectives and the phases of the project, including the anonym treatment of the collected human scalp hair samples and information. In addition, the methods used to protect the identity and privacy of each participant were clearly explicated. A cultural linguistic mediator was present during all the phases of the project involving Eritrean individuals in order to guarantee the complete understanding of all information on research project. The individuals who decided to participate donated the hair sample and filled out an anonym questionnaire. No personally identifying information was collected for assuring the anonymity of each participant.

After washing the hair of each volunteer with shampoo and drying using a previously reported method [36,37], hair samples $(0.1 \mathrm{~g} ; 2 \mathrm{~cm})$ were collected by cutting hair from the occipital region of the head in the same place for both males and females. Stainless steel scissors and disposable vinyl 
gloves were used to avoid contamination. The hair samples were then placed into polyethylene bags, transported to the laboratory, and stored in the dark at room temperature $\left(21^{\circ} \mathrm{C}\right)$ until further analysis.

Table 1. Characteristics of the studied population.

\begin{tabular}{|c|c|c|}
\hline Variable & Studied Population Characteristics & Descriptives in \% if not Stated Otherwise $(N)$ \\
\hline \multirow{3}{*}{ Gender } & Male & $45.8(N=55)$ \\
\hline & Female & $54.2(N=65)$ \\
\hline & Unknown & $0(N=0)$ \\
\hline \multirow{4}{*}{ Occupation } & Work at Medeber & 53.3 ( $N=32$ males; $N=32$ females $)$ \\
\hline & Employed & $19.2(N=9$ males; $N=14$ females $)$ \\
\hline & No work at Medeber: $\quad$ Unknown job & 23.3 ( $N=12$ males; $N=16$ females $)$ \\
\hline & Unknown & $4.2(N=2$ males; $N=3$ females $)$ \\
\hline \multirow{4}{*}{ Smoking habit } & Never smoker & $90.8(N=109)$ \\
\hline & Current smoker & $4.2(N=5)$ \\
\hline & Ex-smoker & $0.8(N=1)$ \\
\hline & Unknown & $4.2(N=5)$ \\
\hline \multirow{4}{*}{ Fish consumption } & Never/Seasonally/Sometimes & $94.2(N=113)$ \\
\hline & Weekly & $4.2(N=5)$ \\
\hline & Daily & $0(N=0)$ \\
\hline & Unknown & $1.6(N=2)$ \\
\hline \multirow{4}{*}{$\begin{array}{l}\text { Body mass index (BMI) } \\
\text { categories }\end{array}$} & Underweight $(<18.5)$ & $26.7(N=32)$ \\
\hline & Normal weight (18.5-24.9) & $57.5(N=69)$ \\
\hline & Overweight/obesity (25-29.9/ 30 or greater) & $11.7(N=14)$ \\
\hline & Unknown & $4.2(N=5)$ \\
\hline \multirow{5}{*}{ Age groups } & Adolescence (15-21 y) & $10.0(N=12)$ \\
\hline & Early adulthood (22-39 y) & $65.0(N=78)$ \\
\hline & Second adult age (40-59 y) & $17.5(N=21)$ \\
\hline & Third age $(\geq 60 \mathrm{y})$ & $4.2(N=5)$ \\
\hline & Unknown & $3.3(N=4)$ \\
\hline Age & & $\begin{array}{c}\mathrm{AM} \pm \mathrm{SD}^{1}=33.6 \pm 11.7 \\
\mathrm{Min}-\mathrm{Max}=15-76\end{array}$ \\
\hline BMI & & $\begin{array}{c}\mathrm{AM} \pm \mathrm{SD}^{1}=21.2 \pm 4.0 \\
\mathrm{Min}-\mathrm{Max}=15.4-44.6\end{array}$ \\
\hline
\end{tabular}

${ }^{1}$ Arithmetic mean (AM) \pm standard deviation (SD).

\subsection{Chemical Analysis}

$\mathrm{Hg}$ exposure for 120 individuals was estimated by measuring total $\mathrm{Hg}$ content in hair samples. These were trimmed in order to analyze the $2 \mathrm{~cm}$ length of hair closest to the scalp. Hair grows at an average rate of one cm per month [38] and, thus, our analysis was intended to estimate the total $\mathrm{Hg}$ exposure for the two-month period preceding analysis. Hair total $\mathrm{Hg}$ content was determined by thermal decomposition-gold amalgamation atomic absorption spectroscopy, as described in a previous paper [39]. Briefly, when the sample arrived to the laboratory, the hair strands were further cut into smaller pieces $(3-5 \mathrm{~mm})$ using stainless scissor. Then, $5 \mathrm{mg}$ of the sample were placed in a nickel boat for Hg determination in the Advanced Mercury Analyzer (AMA-254, Altec Ltd., Prague, Czech Republic). Each sample was analyzed in duplicate and average mean concentrations of total $\mathrm{Hg}\left(\mu \mathrm{g} \mathrm{g}^{-1}\right)$ was used for data treatment in the statistical analysis. Standard stock solution of $\mathrm{Hg}$ (1002 $\pm 7 \mathrm{mg} \mathrm{L}^{-1}$; SCP Science, Baie D’Urfé, Canada) and deionized water (resistivity $\leq 18.3 \mathrm{M} \Omega \mathrm{cm}$ ) generated by an Arioso Power I RO-UP Scholar UV deionizer (Human Corporation, Songpa-Ku, Seoul, Korea) with $1 \% \mathrm{HNO}_{3}$ v/v (assay $>67 \%$; residue $<1 \mathrm{mg} \mathrm{L}^{-1}$; Promochem, LGC Standards GmbH, Wesel, Germany) were used to prepare calibration standards. The instrument calibration was verified by the analysis of a hair standard reference material (ERM-DB001; sample no. 0196; Joint Research Centre, Geel, Belgium) every 10 samples in a batch run. Accepted measurements were within $10 \%$ of certified value. The detection limit was $0.07 \mathrm{ng} \mathrm{Hg}$. 


\subsection{Data Analysis}

Information about the participants was collected by a questionnaire specifically designated for the present study. Questions were translated into Tigrinya (the language spoken in Asmara) and validated before its administration to the studied individuals. Note that, due to the often-illegal nature of mining in the area, we chose not to ask participants about their mining activities. In particular, we collected the following characteristics of each participant: gender, age, height and weight, smoking habits and fish consumption. Then, we coded the collected information and entered it into a database created "ad hoc". Gender was categorized as $0=$ male and $1=$ female; age was entered as the number of years and used as a continuous variable; smoking habits were coded as $0=$ never smoker, $1=$ current smoker and $2=$ ex-smoker; and fish consumption was coded as $0=$ Never/Seasonally/Sometimes, $1=$ weekly and $2=$ daily. We also created the categorical variable "age groups" as follows: adolescence (15-21 years old), early adulthood (22-39 years old), second adult age (40-59 years old) and third age ( $\geq 60$ years old). Body mass index (BMI) was calculated from participants' weight and height. BMI was then used both as a continuous variable and as a recoded categorical variable as follows: underweight $=0$, normal weight $=1$ and overweight/obesity $=2$. The occupational setting of each participant were coded as "not working at Medeber" $=0$ and "work at Medeber" $=1$.

Statistical analyses were performed by the use of IBM SPSS Statistics 25 software (IBM Corp., Armonk, NY, USA). First of all, we elaborated descriptive statistics, reporting categorical variables as absolute and relative frequencies while continuous variables as arithmetic mean (AM) \pm standard deviation (SD) and range (minimum and maximum) value. For evaluating the influences of the collected variables on hair $\mathrm{Hg}$ concentration, we preliminary assessed the normality $\mathrm{Hg}$ level by use of the Kolmogorov-Smirnov test. The results demonstrated that natural log-transformed data were normally distributed. Thus, $t$-tests for independent samples were used to test the statistical significance of the differences in the mean levels of $\mathrm{Hg}$ according to gender and occupational scenario. Besides, a one-way ANOVA test was used to assess differences in the $\mathrm{Hg}$ level based on age groups or BMI categories as categorical variables. Finally, Pearson's correlation coefficients were used to evaluate the association between the $\mathrm{Hg}$ level and the age or BMI (continuous variables) of each participant. The significance level for all tests was $\mathrm{p} \leq 0.05$ (two-tailed).

\section{Results}

The characteristics of the study population are shown in Table 1. A total of 120 participants were recruited, with a similar proportion of males $(45.8 \%)$ and females $(54.2 \%)$. The largest age group was those 22-39 years old (39.0\%). Regarding the occupational scenario, just over half of the individuals worked at the Medeber market (53.3\%), while just under half of the individuals did not work at Medeber. BMI mean value $(21.2 \pm 4.0)$ corresponded to a normal weight (18.5-24.9). A majority of the population has never smoked $(90.8 \%)$ and consumed fish never, or just seasonally or sometimes $(94.2 \%)$. Therefore, we decided not to consider these variables in the subsequent statistical elaboration.

The results of the univariate statistical analyses according to gender, occupational scenario, age and BMI groups are shown in Tables 2 and 3, while the results of the association between the $\mathrm{Hg}$ level and the age or BMI (continuous variables) of each participant are reported in Table 4. Significant differences were found in the mean levels of $\mathrm{Hg}$ according to gender and occupational scenario. Indeed, the $\mathrm{Hg}$ levels were significantly higher in women $\left(2.1 \pm 4.3 \mu \mathrm{g} \mathrm{g}^{-1}\right)$ than in men $\left(0.23 \pm 0.37 \mu \mathrm{g} \mathrm{g}^{-1}\right.$; $p<0.001$; Table 2) and in women who worked in the Medeber market $\left(3.6 \pm 6.0 \mu \mathrm{g} \mathrm{g}^{-1}\right)$ compared to those obtained in all others $(p<0.010$; Table 3$)$. No significant correlations between hair levels of $\mathrm{Hg}$ and BMI or age were found. 
Table 2. Demographics of participants and hair mercury concentrations $\left(\mu \mathrm{g} \mathrm{g}^{-1}\right)$.

\begin{tabular}{|c|c|c|c|c|}
\hline Variable & $\begin{array}{l}\text { Studied Population } \\
\text { Characteristics }\end{array}$ & $\mathrm{AM} \pm \mathrm{SD}^{1}$ & $\begin{array}{c}\text { Median } \\
\text { (Min-Max) }\end{array}$ & $p$-Value ${ }^{2}$ \\
\hline \multirow{3}{*}{ Gender } & Male & $0.23 \pm 0.37$ & $0.10(0.03-2.24)$ & \multirow{3}{*}{$<0.001$} \\
\hline & Female & $2.1 \pm 4.3$ & $0.30(0.01-21.4)$ & \\
\hline & Overall & $1.3 \pm 3.3$ & $0.16(0.01-21.4)$ & \\
\hline \multirow{2}{*}{ Work at Medeber } & No & $0.7 \pm 1.8$ & $0.13(0.01-10.1)$ & \multirow{2}{*}{0.132} \\
\hline & Yes & $1.7 \pm 4.3$ & $0.16(0.02-21.4)$ & \\
\hline \multirow{4}{*}{ Age groups } & Adolescence (15-21 y) & $0.29 \pm 0.36$ & $0.13(0.03-1.22)$ & \multirow{4}{*}{0.680} \\
\hline & Early adulthood (22-39 y) & $1.5 \pm 3.9$ & $0.16(0.02-21.4)$ & \\
\hline & Second adult age (40-59 y) & $0.8 \pm 2.0$ & $0.13(0.01-8.2)$ & \\
\hline & Third age $(\geq 60 y)$ & $0.7 \pm 1.0$ & $0.27(0.1-1.5)$ & \\
\hline \multirow{3}{*}{$\begin{array}{l}\text { Body mass index } \\
\text { (BMI) categories }\end{array}$} & Underweight $(<18.5)$ & $0.7 \pm 1.7$ & $0.09(0.03-8.2)$ & \multirow{3}{*}{0.774} \\
\hline & Normal weight (18.5-24.9) & $1.4 \pm 3.3$ & $0.17(0.01-21.4)$ & \\
\hline & $\begin{array}{l}\text { Overweight/obesity (25-29.9/ } \\
30 \text { or greater) }\end{array}$ & $1.7 \pm 5.6$ & $0.14(0.04-21.2)$ & \\
\hline
\end{tabular}

Table 3. Association between the mercury level $\left(\mu \mathrm{g} \mathrm{g}^{-1}\right)$ in hair and gender/occupational scenario.

\begin{tabular}{cccccc}
\hline \multirow{2}{*}{ Gender/Occupation } & \multicolumn{2}{c}{ Not work at Medeber } & \multicolumn{2}{c}{ Work at Medeber } & \multirow{2}{*}{-Value $^{\mathbf{1}}$} \\
\cline { 2 - 5 } & $\mathbf{A M} \pm \mathbf{S D}^{\mathbf{2}}$ & Median $\pm \mathbf{I Q R}^{\mathbf{3}}$ & $\mathbf{A M} \pm \mathbf{S D}$ & ${\text { Median } \pm \mathbf{I Q R}^{\mathbf{3}}}$ \\
\hline Females & $1.0 \pm 2.3$ & $0.14 \pm 0.41$ & $3.6 \pm 6.0$ & $0.6 \pm 4.1$ & 0.010 \\
Males & $0.22 \pm 0.28$ & $0.13 \pm 0.18$ & $0.24 \pm 0.43$ & $0.08 \pm 0.21$ & 0.492 \\
\hline -value & & \multicolumn{2}{c}{$<0.323$} & $<01$ & \\
\hline
\end{tabular}

${ }^{1}$ All variables were compared using an unpaired $t$-test (natural log-transformed data). ${ }^{2}$ Arithmetic mean (AM);

\pm standard deviation (SD). ${ }^{3} \mathrm{IQR}=$ interquartile range.

Table 4. Univariate statistical analysis in the studied population according to age and body mass index (BMI).

\begin{tabular}{|c|c|c|}
\hline Variable & Pearson's Correlation Coefficient $^{1}$ & $p$-Value ${ }^{1}$ \\
\hline Age & -0.003 & 0.974 \\
\hline Body mass index (BMI) & 0.095 & 0.313 \\
\hline
\end{tabular}

\section{Discussion}

In the last years, several studies conducted in European countries [40-45], USA [46], Canada [47], Japan [48] and China [49] demonstrated that exposure to $\mathrm{Hg}$ is still a crucial public health concern, which no one country can solve alone. In 2013, the Minamata Convention adopted comprehensive measures to eliminate or at least reduce the sources of emission and exposure to $\mathrm{Hg}$ (http://Www. mercuryconvention.org). Currently, the collaboration between the World Health Organization (WHO) European Center for Environment and Health and the United Nations Environment Program (UNEP) aims to plan human biomonitoring at a global level as a key tool to evaluate the baseline conditions of human exposure to $\mathrm{Hg}$ and to reduce this exposure and the relevant risks [8].

In this study, hair $\mathrm{Hg}$ concentrations were below the WHO No Observed Adverse Effect Level (NOAEL; $50 \mu \mathrm{g} \mathrm{g}^{-1}$ ) [30], however in $26.7 \%$ of people exceeded the United States Environmental Protection Agency (USEPA) reference dose of $1.2 \mathrm{\mu g} \mathrm{g}^{-1}$ [38,50]. In addition, the $\mathrm{Hg}$ levels in some hair samples of women also exceeded the NOAEL $\left(10 \mu \mathrm{g} \mathrm{g}^{-1}\right)$ associated with fetus neurotoxicity [51,52]. Communities near mining may have unexpected dietary sources or can be exposed to other $\mathrm{Hg}$ species [12,53]. Since the $\mathrm{Hg}$ in hair is typically dominated by $\mathrm{MeHg}$ species [32], diet is often presumed 
to be the dominant exposure route; however, a fraction of $\mathrm{Hg}$ in hair could be the inorganic form caused by other dietary and non-dietary routes (e.g., inorganic Hg exposure from gold amalgamation) [12,54]. Laffont et al. [54] found that modeled inorganic Hg levels in hair samples correspond well to measured inorganic $\mathrm{Hg}$ concentrations, demonstrating that inorganic $\mathrm{Hg}$ exposure sources to gold miners can be monitored by the use of hair samples. Although there are more appropriate biomarkers to assess inorganic $\mathrm{Hg}$ [55], we chose to use hair because it is a stable matrix with easy collection, transport and storage [33]. This is very important when considering biomonitoring in developing countries and remote areas where immediate sample cooling to $4{ }^{\circ} \mathrm{C}$ or even freezing below $-18{ }^{\circ} \mathrm{C}$ to prevent degradation and to reduce bacterial growth is not available $[33,34]$. Although the urine matrix is the standard biomarker to assess the exposure to inorganic $\mathrm{Hg}$ through a non-invasive approach, urinary sediments tends to precipitate during the storage period. Trace elements in urine may coprecipitate, or adsorb onto the surface of the precipitates [56]. In particular, $\mathrm{Hg}$ was found to be concentrated in the precipitate of acidified urine after two days' storage [56].

Our data indicate that some women who prepare spices in the Medeber market are exposed to higher $\mathrm{Hg}$ levels than others workers. Despite that the study population did not consume fish regularly, hair $\mathrm{Hg}$ concentration was significantly higher among women compared to men $(p<0.001)$ and among women preparing spicy products in the Medeber market compared to those who did other jobs $(p=0.010)$. Hair Hg concentrations in $53.1 \%$ of women employed in the Medeber market exceeded the USEPA reference dose of $1.2 \mu \mathrm{g} \mathrm{g}^{-1}$. In fact, plants can also contain $\mathrm{Hg}$ due to the bioaccumulation of $\mathrm{Hg}$ from soil, water and atmosphere [57]. In recent years, there has been a growing interest in monitoring heavy metal contamination of spices [57-59]. These can contain toxic elements in a wide range of concentrations, and their content can vary according to the location and the type of soil for cultivation, fertilizers, herbicides and water resources used for irrigation, climate and environmental pollution levels [58]. The levels of toxic elements (like $\mathrm{As}, \mathrm{Cd}, \mathrm{Hg}$ and $\mathrm{Pb}$ ) in pepper, ginger and black cumin, reported in previous studies [58], exceed in many cases the maximum limits allowed regulated by different legislations $[60,61]$ and recommendations by WHO $[62,63]$.

Previous studies showed that gender is unlikely to be an important factor determining $\mathrm{Hg}$ accumulation in hair [64-69]. However, other studies found that males had higher mean values of $\mathrm{Hg}$ concentrations in hair than females in Italy and Spain $[15,44]$. These gender-related differences could be due to a higher fish consumption per serving in males than in females or the possible $\mathrm{Hg}$ elimination in females as a result of different hair treatments, such as artificial hair waving and hair coloring/dyeing [15].

The relationship of hair $\mathrm{Hg}$ concentration with age is of interest. Few studies have looked at the effect of age on hair $\mathrm{Hg}$ concentration [67,70-75]. Our results show that there were no significant correlations between $\mathrm{Hg}$ concentrations and age $(p=0.974$, Table 4$)$ in accord with other studies $[67,71,72]$. In contrast, other authors showed that the $\mathrm{Hg}$ level in hair increases with age [73-75].

Our finding that total hair $\mathrm{Hg}$ levels were statistically significantly higher in women preparing spices, supports the idea that anthropogenic activities increase the risk of $\mathrm{Hg}$ exposure and suggests that further studies include a consideration of nutritional, occupational and residential exposures.

Our study had several important limitations. First, the present study was a cross-sectional study, therefore, it did not allow an evaluation over time. Second, we did not know whether people engaged in mining took part in it. Third, we did not analyze the spices processed in the Medeber market. Fourth, we had no data on $\mathrm{Hg}$ levels in blood that would be useful for comparison with the data obtained in hair. Nevertheless, to our knowledge, it is important to note that this is the first human biomonitoring study performed on Eritrean individuals using hair samples to assess $\mathrm{Hg}$ exposure.

\section{Conclusions}

The results of the present study evidenced that gender was an important interfering factor on the hair concentrations of $\mathrm{Hg}$. Consequently, the use of gender specific reference ranges was strongly recommended in human biomonitoring studies performing to assess human health risks related to $\mathrm{Hg}$ 
exposure. Furthermore, our findings indicate the relevance of the occupational scenario on the $\mathrm{Hg}$ exposure of the monitored population. This indicates the presence of high $\mathrm{Hg}$ sources in this site. As a result, health promotion campaigns are needed to increase health and safety protection strategies for the Medeber workers, such as the use of gloves and masks or other appropriated personal protective equipment. In addition, human biomonitoring studies would be needed to verify whether imposed controls, and health and safety promotions are effectives. These in-field data on $\mathrm{Hg}$ levels in hair matrix can be used as baseline information for future programs aimed to control environmental pollution, particularly in developing countries.

Author Contributions: Conceptualization, M.L.A. and M.B.; Data curation, M.L.A.; Formal analysis, C.P. and L.M.; Investigation, E.M.; Resources, D.P., M.B. and S.C.; Supervision, M.L.A., M.V. and S.C.; Validation, M.L.A.; Visualization, E.M. and L.M.; Writing—original draft, M.L.A.; Writing—review and editing, M.L.A., C.P., M.V. and S.C. All authors have read and agree to the published version of the manuscript.

Funding: This research received no external funding.

Acknowledgments: The authors would like to thank all the participants.

Conflicts of Interest: The authors declare no conflict of interest.

\section{References}

1. Lamborg, C.H.; Hammerschmidt, C.R.; Bowman, K.L.; Swarr, G.J.; Munson, K.M.; Ohnemus, D.C.; Lam, P.J.; Heimbürger, L.E.; Rijkenberg, M.J.A.; Saito, M.A. A global ocean inventory of anthropogenic mercury based on water column measurements. Nature 2014, 512, 65-68. [CrossRef]

2. Baeyens, W.; Leermakers, M.; Papina, T. Bioconcentration and biomagnification of mercury and methylmercury in North Sea and Scheldt Estuary Fish. Arch. Envriron. Contam. Toxicol. 2003, 45, 498-508. [CrossRef]

3. Bravo, M.A.; Parra, S.; Quiroz, W.; Neaman, A. Human exposure assessment to mercury through hair analysis in coastal villages of the Valparaiso region (Chile). J. Chil. Chem. Soc. 2019, 64, 4480-4483. [CrossRef]

4. Li, X.; Wang, Z. Determination of mercury by intermittent flow electrochemical cold vapor generation coupled to atomic fluorescence spectrometry. Anal. Chim. Acta 2007, 588, 179-183. [CrossRef]

5. Esteban, M.; Schindler, B.K.; Jiménez, J.A.; Koch, H.M.; Angerer, J.; Rosado, M.; Gómez, S.; Casteleyn, L.; Kolossa-Gehring, M.; Becker, K.; et al. Mercury analysis in hair: Comparability and quality assessment within the transnational COPHES/DEMOCOPHES project. Environ. Res. 2014, 141, 24-30. [CrossRef] [PubMed]

6. Boerleider, R.; Roeleveld, N.; Scheepers, P. Human biological monitoring of mercury for exposure assessment. AIMS Environ. Sci. 2017, 4, 251-276. [CrossRef]

7. World Health Organization (WHO)-United Nations Environment Programme (UNEP). Guidance for Identifying Populations at Risk from Mercury Exposure. Available online: https://wedocs.unep.org/ bitstream/handle/20.500.11822/11786/IdentifyingPopnatRiskExposuretoMercury_2008Web.pdf. (accessed on 10 December 2019).

8. World Health Organization (WHO). Human Biomonitoring: Facts and Figures. WHO Regional Office for Europe, Copenhagen. 2015. Available online: http:/www.euro.who.int/en/media-centre/events/ events/2015/04/ehp-mid-termreview/publications/human-biomonitoring-facts-and-figures (accessed on 10 December 2019).

9. Jia, Q.; Zhu, X.; Hao, Y.; Yang, Z.; Wang, Q.; Fu, H.; Yu, H. Mercury in soil, vegetable and human hair in a typical mining area in China: Implication for human exposure. J. Environ. Sci. 2018, 68, 73-82. [CrossRef] [PubMed]

10. Okati, N.; Esmaili-sari, A. Hair mercury and risk assessment for consumption of contaminated seafood in residents from the coast of the Persian Gulf, Iran. Environ. Sci. Pollut. Res. 2018, 25, 639-657. [CrossRef] [PubMed]

11. Marín, S.; Pardo, O.; Baguena, R.; Font, G.; Yusà, V. Dietary exposure to trace elements and health risk assessment in the region of Valencia, Spain: A total diet study. Food Addit. Contam. 2017, 34, 228-240. [CrossRef] [PubMed] 
12. Wyatt, L.; Ortiz, E.J.; Feingold, B.; Berky, A.; Diringer, S.; Morales, A.M.; Jurado, E.R.; Hsu-Kim, H.; Pan, W. Spatial, temporal, and dietary variables associated with elevated mercury exposure in Peruvian riverine communities upstream and downstream of artisanal and small-scale gold mining. Int. J. Environ. Res. Public Health 2017, 14, 1582. [CrossRef]

13. United Nations Environment Programme (UNEP). Global Mercury Assessment. Available online: http: //www.eurocbc.org/final-assessment-report-25nov02.pdf (accessed on 14 March 2020).

14. World Health Organization (WHO). Primary Care, Now More than Ever. Available online: https://apps.who. int/medicinedocs/documents/s22232en/s22232en.pdf (accessed on 14 March 2020).

15. Díez, S.; Esbrí, J.M.; Tobias, A.; Higueras, P.; Martínez-Coronado, A. Determinants of exposure to mercury in hair from inhabitants of the largest mercury mine in the world. Chemosphere 2011, 84, 571-577. [CrossRef] [PubMed]

16. Emel, J.; Plisinski, J.; Rogan, J. Monitoring geomorphic and hydrologic change at mine sites using satellite imagery: The Geita gold mine in Tanzania. Appl. Geogr. 2014, 54, 243-249. [CrossRef]

17. Schueler, V.; Kuemmerle, T.; Schröder, H. Impacts of surface gold mining on land use systems in Western Ghana. Ambio 2011, 40, 528-539. [CrossRef] [PubMed]

18. Snapir, B.; Simms, D.M.; Waine, T.W. Mapping the expansion of galamsey gold mines in the cocoa growing area of Ghana using optical remote sensing. Int. J. Appl. Earth Obs. 2017, 58, 225-233. [CrossRef]

19. Wołowiec, P.; Michalak, I.; Chojnacka, K.; Mikulewicz, M. Hair analysis in health assessment. Clin. Chim. Acta 2013, 419, 139-171. [CrossRef]

20. Zahir, F.; Rizwi, J.; Haq, S.; Khan, R. Low dose mercury toxicity and human health. Environ. Toxicol. Pharmacol. 2005, 20, 351-360. [CrossRef]

21. Agency for Toxic Substances and Disease Registry (ATSDR). Toxicological profile for mercury. In U.S. Department of Health and Human Services; Public Health Service: Atlanta, GA, USA, 1999.

22. Pérez, R.; Domenech, E.; Coscollà, C.; Yusà, V. Human Biomonitoring of food contaminants in Spanish children: Design, sampling and lessons learned. Int. J. Hyg. Environ. Health 2017, 220, 1242-1251. [CrossRef]

23. Vitali, M.; Antonucci, A.; Owczarek, M.; Guidotti, M.; Astolfi, M.L.; Manigrasso, M.; Avino, P.; Bhattacharya, B.; Protano, C. Air quality assessment in different environmental scenarios by the determination of typical heavy metals and Persistent Organic Pollutants in native lichen Xanthoria parietina. Environ. Pollut. 2019, 254, 113013. [CrossRef]

24. Astolfi, M.L.; Protano, C.; Schiavi, E.; Marconi, E.; Capobianco, D.; Massimi, L.; Ristorini, M.; Baldassarre, M.E.; Laforgia, N.; Vitali, M.; et al. A prophylactic multi-strain probiotic treatment to reduce the absorption of toxic elements: In-vitro study and biomonitoring of breast milk and infant stools. Environ. Int. 2019, 130, 104818. [CrossRef]

25. Protano, C.; Canepari, S.; Astolfi, M.L.; De Meo, S.D.O.; Vitali, M. Urinary reference ranges and exposure profile for lithium among an Italian paediatric population. Sci. Total Environ. 2018, 619, 58-64. [CrossRef]

26. Astolfi, M.L.; Marconi, E.; Protano, C.; Vitali, M.; Schiavi, E.; Mastromarino, P.; Canepari, S. Optimization and validation of a fast digestion method for the determination of major and trace elements in breast milk by ICP-MS. Anal. Chim. Acta 2018, 1040, 49-62. [CrossRef] [PubMed]

27. Di Dato, C.; Gianfrilli, D.; Greco, E.; Astolfi, M.L.; Canepari, S.; Lenzi, A.; Isidori, A.M.; Giannetta, E. Profiling of selenium absorption and accumulation in healthy subjects after prolonged l-selenomethionine supplementation. J. Endocrinol. Invest. 2017, 40, 1183-1190. [CrossRef] [PubMed]

28. Protano, C.; Astolfi, M.L.; Canepari, S.; Andreoli, R.; Mutti, A.; Valeriani, F.; Romano Spica, V.; Antonucci, A.; Mattei, V.; Martellucci, S.; et al. Exposure to individual and multiple carcinogenic metals during pediatric age: An experience from an Italian urban scenario. Ann. Ig. 2017, 29, 494-503. [CrossRef] [PubMed]

29. Chen, G.; Chen, X.; Yan, C.; Wu, X.; Zeng, G. Surveying mercury levels in hair, blood and urine of under 7-year old children from a coastal city in China. Int. J. Environ. Res. Publ. Health 2014, 11, 12029-12041. [CrossRef] [PubMed]

30. European Food Safety Authority (EFSA). Scientific Opinion on the risk for public health related to the presence of mercury and methylmercury in food. EFSA J. 2012, 10, 2985 . Available online: http://old.iss.it/binary/meta/cont/2985_Scientific_Opinion_on_the_risk_for_public_health_related_ to_the_presence_of_mercury_and_methylmercury_in_food.pdf (accessed on 29 February 2020). 
31. World Health Organisation (WHO). International Programme on Chemical Safety. In Environmental Health Criteria 101: Methyl Mercury; World Health Organization: Geneva, Switzerland, 1990; Available online: https:/apps.who.int/iris/bitstream/handle/10665/38082/9241571012_eng.pdf;jsessionid= 3E678184AC10084FB382D9943A68BE48? sequence=1 (accessed on 29 February 2020).

32. Protano, C.; Astolfi, M.L.; Marconi, E.; Antonucci, A.; Canepari, S.; Piamonti, D.; Brunori, M.; Vitali, M. Occupational exposure assessment of major and trace elements in human scalp hair among a group of Eritrean workers. Biol. Trace Elem. Res. 2019, 1-12. [CrossRef]

33. Esteban, M.; Castaño, A. Non-invasive matrices in human biomonitoring: A review. Environ. Int. 2009, 35 , 438-449. [CrossRef]

34. Pozebon, D.; Scheffler, G.L.; Dressler, V.L. Elemental hair analysis: A review of procedures and applications. Anal. Chim. Acta 2017, 992, 1-23. [CrossRef]

35. Mussie Tesfagiorgis, G. Eritrea. ABC-CLIO; Greenwood Publishing Group: Santa Barbara, CA, USA, 2010.

36. Chojnacka, K.; Michalak, I.; Zielińska, A.; Górecka, H.; Górecki, H. Inter-relationship between elements in human hair: The effect of gender. Ecotoxicol. Environ. Saf. 2010, 73, 2022-2028. [CrossRef]

37. Szynkowska, M.I.; Marcinek, M.; Pawlaczyk, A.; Albińska, J. Human hair analysis in relation to similar environmental and occupational exposure. Environ. Toxicol. Pharmacol. 2015, 40, 402-408. [CrossRef]

38. National Research Council (NRC). Toxicological Effects of Methylmercury; National Academy Press: Washington, DC, USA, 2000.

39. Astolfi, M.L.; Protano, C.; Marconi, E.; Piamonti, D.; Massimi, L.; Brunori, M.; Vitali, M.; Canepari, S. Simple and rapid method for the determination of mercury in human hair by cold vapour generation atomic fluorescence spectrometry. Microchem. J. 2019, 150, 104186. [CrossRef]

40. Gundacker, C.; Frohlich, S.; Graf-Rohrmeister, K.; Eibenberger, B.; Jessenig, V.; Gicic, D.; Prinz, S.; Wittmann, K.J.; Zeisler, H.; Vallant, B.; et al. Perinatal lead and mercury exposure in Austria. Sci. Total Environ. 2010, 408, 5744-5749. [CrossRef] [PubMed]

41. Croes, K.; De Coster, S.; De Galan, S.; Morrens, B.; Loots, I.; Van de Mieroop, E.; Nelen, V.; Sioen, I.; Bruckers, L.; Nawrot, T.; et al. Health effects in the Flemish population in relation to low levels of mercury exposure: From organ to transcriptome level. Int. J. Hyg. Environ. Health 2014, 217, 239-247. [CrossRef] [PubMed]

42. Guldner, L.; Monfort, C.; Rouget, F.; Garlantezec, R.; Cordier, S. Maternal fish and shellfish intake and pregnancy outcomes: A prospective cohort study in Brittany, France. Environ. Health 2007, 33, 1-8. [CrossRef]

43. Miklavčič, A.; Casetta, A.; Snoj Tratnik, J.; Mazej, D.; Krsnik, M.; Mariuz, M.; Sofianou, K.; Špirić, Z.; Barbone, F.; Horvat, M. Mercury, arsenic and selenium exposure levels in relation to fish consumption in the Mediterranean area. Environ. Res. 2013, 120, 7-17. [CrossRef]

44. Díez, S.; Montuori, P.; Pagano, A.; Sarnacchiaro, P.; Bayona, J.M.; Triassi, M. Hair mercury levels in an urban population from southern Italy: Fish consumption as a determinant of exposure. Environ. Int. 2008, 34, 162-167. [CrossRef]

45. Díez, S.; Delgado, S.; Aguilera, I.; Astray, J.; Pérez-Gómez, B.; Torrent, M.; Sunyer, J.; Bayona, J.M. Prenatal and early childhood exposure to mercury and methylmercury in Spain, a high-fish-consumer country. Arch. Environ. Contam. Toxicol. 2009, 56, 615-622. [CrossRef]

46. Mahaffey, K.R. Mercury exposure: Medical and public health issues. Trans. Am. Clin. Climatol. Assoc. 2005, $116,127-153$.

47. Plusquellec, P.; Muckle, G.; Dewailly, E.; Ayotte, P.; Begin, G.; Desrosiers, C.; Després, C.; Saint-Amour, D.; Poitras, K. The relation of environmental contaminants exposure to behavioral indicators in Inuit preschoolers in Arctic Quebec. Neurotoxicology 2010, 31, 17-25. [CrossRef]

48. Sakamoto, M.; Kaneoka, T.; Murata, K.; Nakai, K.; Satoh, H.; Akagi, H. Correlations between mercury concentrations in umbilical cord tissue and other biomarkers of fetal exposure to methylmercury in the Japanese population. Environ. Res. 2007, 103, 106-111. [CrossRef]

49. Jin, L.; Liu, J.; Ye, B.; Ren, A. Concentrations of selected heavy metals in maternal blood and associated factors in rural areas in Shanxi Province, China. Environ. Int. 2014, 66, 157-164. [CrossRef] [PubMed]

50. United States Environmental Protection Agency (USEPA). Methylmercury reference dose for chronic oral exposure. Available online: https://cfpub.epa.gov/ncea/iris/iris_documents/documents/subst/0073_summary. pdf (accessed on 7 January 2020). 
51. Grandjean, P.; Weihe, P.; White, R.F.; Debes, F.; Araki, S.; Yokoyama, K.; Murata, K.; Sorensen, N.; Dahl, R.; Jorgensen, P.J. Cognitive deficit in 7-year-old children with prenatal exposure to methylmercury. Neurotoxicol.Teratol. 1997, 19, 417-428. [CrossRef]

52. Grandjean, P.; White, R.F.; Nielsen, A.; Cleary, D.; de Oliveira Santos, E.C. Methylmercury neurotoxicity in Amazonian children: Downstream from gold mining. Environ. Health Persp. 1999, 107, 587-591. [CrossRef] [PubMed]

53. Langeland, A.L.; Hardin, R.D.; Neitzel, R.L. Mercury levels in human hair and farmed fish near artisanal and small-scale gold mining communities in the Madre de Dios River Basin, Peru. Int. J. Environ. Res. Public Health 2017, 14, 302. [CrossRef]

54. Laffont, L.; Sonke, J.E.; Maurice, L.; Monrroy, S.L.; Chincheros, J.; Amouroux, D.; Behra, P. Hg speciation and stable isotope signatures in human hair as a tracer for dietary and occupational exposure to mercury. Environ. Sci. Technol. 2011, 45, 9910-9916. [CrossRef]

55. Branco, V.; Caito, S.; Farina, M.; Teixeira da Rocha, J.B.; Aschner, M.; Carvalho, C. Biomarkers of mercury toxicity: Past, present and future trends. J. Toxicol. Environ. Health B Crit. Rev. 2017, 20, 119-154. [CrossRef]

56. Herber, R.F.M.; Stoeppler, M. Trace Element Analysis in Biological Specimens; Elsevier: Amsterdam, The Netherlands, 1994.

57. Nkansah, M.A.; Amoako, C.O. Heavy metal content of some common spices available in markets in the Kumasi metropolis of Ghana. Am. J. Sci. Ind. Res. 2010, 1, 158-163. [CrossRef]

58. Blagojević, S.; Blagojević, S.; Begović, B. Lead, mercury and arsenic content in spices: Black, white and green pepper, black cumin and ginger. Facta. Univ. -Ser. Phys. Chem. Tech. 2015, 13, 191-202. [CrossRef]

59. Shim, J.; Cho, T.; Leem, D.; Cho, Y.; Lee, C. Heavy metals in spices commonly consumed in Republic of Korea. Food Addit. Contam. B 2019, 12, 52-58. [CrossRef]

60. European Commission (EC). Commision Regulation No 149/2008 of 29 January 2008 amending Regulation (EC) No 396/2005 of the European Parliament and of the Council by establishing Annexes II, III and IV setting maximum residue levels for products covered by Annex I thereto. O. J. E. U. 2008, 58, 1-398.

61. European Commission (EC). Commission Regulation No 629/2008 of 2 July 2008 amending Regulation (EC) No 1881/2006 setting maximum levels for certain contaminants in foodstuffs. O. J. E. U. 2008, 173, 6-9.

62. World Health Organization (WHO). WHO Guidelines for Assessing Quality of Herbal Medicines with Reference to Contaminants and Residues; World Health Organization: Geneva, Switzerland, 2007; Available online: http://apps.who.int/medicinedocs/documents/s14878e/s14878e.pdf (accessed on 7 January 2020).

63. Codex Alimentarius Commission. Joint FAO/WHO Food Standards Programme Codex Committee on Contaminants in Foods. Fifth Session. Available online: http://www.fao.org/tempref/codex/Meetings/CCCF/ CCCF5/cf05_INF.pdf (accessed on 14 March 2020).

64. Kosatsky, T.; Przybysz, R.; Armstrong, B. Mercury exposure in Montrealers who eat St. Lawrence River sport fish. Environ. Res. 2000, 84, 36-43. [CrossRef] [PubMed]

65. Mortada, W.I.; Sobh, M.A.; El-Defrawy, M.M.; Farahat, S.E. Reference intervals of cadmium, lead, and mercury in blood, urine, hair, and nails among residents in Mansoura City, Nile Delta, Egypt. Environ. Res. 2002, 90, 104-110. [CrossRef] [PubMed]

66. Olivero, J.; Johnson, B.; Arguello, E. Human exposure to mercury in San Jorge river basin, Colombia (South America). Sci. Total Environ. 2002, 289, 41-47. [CrossRef]

67. Agusa, T.; Kunito, T.; Iwata, I.; Monirith, I.; Tana, T.S.; Subramanian, A.; Tanabe, S. Mercury contamination in human hair and fish from Cambodia: Levels, specific accumulation and risk assessment. J. Environ. Pollut. 2005, 134, 79-86. [CrossRef]

68. Michalak, I.; Chojnacka, K.; Saeid, A.; Mikulewicz, M. Research on mercury levels in scalp hair. Pol. J. Environ. Stud. 2014, 23, 793-800. [CrossRef]

69. Knobeloch, L.; Gliori, G.; Anderson, H. Assessment of methyl mercury exposure in Wisconsin. Environ. Res. 2007, 103, 205-210. [CrossRef]

70. Gibb, H.; O’Leary, K.G.; Sarkar, S.K.; Wang, J.; Liguori, L.; Rainis, H.; Smith, K.A.; Chatterjee, M. Hair mercury concentrations in residents of Sundarban and Calcutta, India. Environ. Res. 2016, 150, 616-621. [CrossRef]

71. Peplow, D.; Augustine, S. Community-led assessment of risk from exposure to mercury by native Amerindian Wayana in Southeast Suriname. J. Environ. Public Health 2012, 2012, 1-10. [CrossRef]

72. Fakour, H.; Esmaili-Sari, A.; Zayeri, F. Mercury exposure assessment in Iranian women's hair of a port town with respect to fish consumption and amalgam fillings. Sci. Total Environ. 2010, 408, 1538-1543. [CrossRef] 
73. Barbieri, F.L.; Cournil, A.; Gardon, J. Mercury exposure in a high fish eating Bolivian Amazonian population with intense small-scale gold-mining activities. Int. J. Environ. Health Res. 2009, 19, 267-277. [CrossRef] [PubMed]

74. Santos, E.C.; Câmara, V.M.; Jesus, I.M.; Brabo, E.S.; Lourero, E.C.; Mascarenhas, A.F.; Fayal, K.F.; Sá Filho, G.C.; Sagica, F.E.; Lima, M.O.; et al. A contribution to the establishment of reference values for total mercury levels in hair and fish in Amazonia. Environ. Res. 2002, 90, 6-11. [CrossRef] [PubMed]

75. Liu, J.L.; Xu, X.R.; Yu, S.; Cheng, H.; Peng, J.X.; Hong, Y.G.; Feng, X.B. Mercury contamination in fish and human hair from Hainan Island, South China Sea: Implications for human exposure. Environ. Res. 2014, 135, 42-47. [CrossRef] [PubMed]

(C) 2020 by the authors. Licensee MDPI, Basel, Switzerland. This article is an open access article distributed under the terms and conditions of the Creative Commons Attribution (CC BY) license (http://creativecommons.org/licenses/by/4.0/). 